Jurnal Perikanan (2020) Volume 10. No. 2 : 123-133

DOI : https://doi.org/10.29303/jp.v10i2.185

\title{
ANALISIS PERTUMBUHAN Spirulina sp. DENGAN KOMBINASI PUPUK YANG BERBEDA
}

\section{GROWTH ANALYSIS OF Spirulina sp. WITH DIFFERENT COMBINATION OF FERTILIZER}

\author{
Nilam Cahya ${ }^{1)}$, Ir. Saptono Waspodo ${ }^{1)}$, Bagus Dwi Hari Setyono ${ }^{1)}$ \\ Program Studi Budidaya Perairan, Fakultas Pertanian, Universitas Mataram \\ *)alamat korespondensi : putrianjani83162@gmail.com
}

\begin{abstract}
Abstrak
Penelitian ini bertujuan untuk mengetahui pengaruh pemberian kombinasi pupuk (urea, NPK dan TSP) dengan dosisberbeda terhadap pertumbuhan Spirulina sp. Penelitian ini dilaksanakan pada tanggal 11 Oktober sampai 19 Oktober 2019 yang bertempat di Instalasi Pribadi Jl. Sultan Salahudin Gg. Manggis Perumahan Graha Cendana Blok J no 4, Sekarbela, Kota Mataram. Metode yang digunakan dalam penelitian ini yaitu Rancangan Acak Lengkap (RAL), dengan 4 perlakuan dan 3 ulangan. Masing-masing perlakuan yaitu: Perlakuan A:(0 ml/1 Urea; 0 ml/1 NPK; 0 ml/1 TSP) (kontrol), Perlakuan B: (1 ml/1 Urea; 0,05 ml/1 NPK; 0,02 ml/1 TSP), Perlakuan C:(1,5 ml/1 Urea; 0,1 ml/1 NPK; 0,03 ml/1 TSP), Perlakuan D:(2 ml/1 Urea; 0,15 $\mathrm{ml} / 1 \mathrm{NPK} ; 0,04 \mathrm{ml} / 1 \mathrm{TSP})$. Hasil penelitian selama 9 hari proses kultur pada perlakuan D dengan kombinasi pupuk (urea, NPK, dan TSP) sebanyak (0,4 g/1 Urea; 0,04 g/1 NPK; 0,008 g/1 TSP) didapat hasil kepadatan tertinggi yaitu sebanyak $831 \mathrm{ind} / \mathrm{ml}$ sedangkan nilai terendah didapat pada perlakuan A (tanpa pupuk) yaitu sebanyak $505 \mathrm{ind} / \mathrm{ml}$ dan laju pertumbuhan harian tertinggi didapat pada perlakuan D dengan kombinasi pupuk (urea, NPK, dan TSP) sebanyak (0,4 g/l Urea; 0,04 g/l NPK; 0,008 g/l TSP) yaitu sebanyak $0.413 \mathrm{ind} / \mathrm{ml} / \mathrm{hari}$ sedangkan nilai terendah didapat pada perlakuan A (tanpa pupuk) yaitu sebanyak $0.484 \mathrm{ind} / \mathrm{ml} / \mathrm{hari}$.
\end{abstract}

Kata kunci: Pupuk, Spirulina sp., Kepadatan Puncak Populasi, dan Laju Pertumbuhan Harian.

\begin{abstract}
This study aims to providing a combination of fertilizer (urea, NPK dan TSP) with different doses on the growth of Spirulina sp. This research was conducted in October 2019 which took place in a private graham cendana Blok J no 4, Sekarbela, Mataram City. This study uses a completely randomized design with four treatment namely treatment A: $(0 \mathrm{~g} / 1 \mathrm{Urea} ; 0 \mathrm{~g} / 1$ NPK; 0 g/1 TSP) (kontrol), B: (0,2 g/1 Urea; 0, 01g/1 NPK; 0,004 g/1 TSP), C: (0,3 g/1 Urea; 0,02 g/1 NPK; 0,006 g/1 TSP), D: (0,4 g/l Urea; 0,04 g/l NPK; 0,008 g/1 TSP). The results of the study for 9 days of culture process in treatment $\mathrm{D}$ with a combination of fertilizer (urea, NPK dan TSP) as much $(0,4 \mathrm{~g} / 1$ Urea; $0,04 \mathrm{~g} / 1 \mathrm{NPK} ; 0,008 \mathrm{~g} / 1 \mathrm{TSP})$ the highes density results obtained as much as $831 \mathrm{ind} / \mathrm{ml}$ while the lowest value obtained in treatment A (without fertilizer) is as much 505 ind $/ \mathrm{ml}$ and the highest daily growth rate is obtained in treatment $\mathrm{D}$ with a combination of fertilizer (urea, NPK dan TSP) (0,4 g/1 Urea; 0,04 g/1 NPK; 0,008 g/1 TSP) this is as much as $0.413 \mathrm{ind} / \mathrm{ml} /$ day while the lowest value obtained in treatment $\mathrm{A}$ (without fertilizer) is 0.484 ind $/ \mathrm{ml} /$ day.
\end{abstract}


Keywords: Spirulina sp. Fertilizer, Peak density, and daily growth rate

\section{PENDAHULUAN}

Pakan adalah makanan yang dimanfaatkan atau yang dimakan hewan, termasuk ikan untuk kelangsungan hidup dan pertumbuhan tubuhnya. Pakan yang mengandung nilai gizi yang baik akan membantu pertumbuhan yang optimal pada ikan. Kebutuhan protein bagi ikan dapat diperoleh dari pakan alami dan pakan buatan. Menurut Amri dkk (2018), pakan alami merupakan makanan ikan yang tumbuh dialam tanpa campur tangan manusia secara langsung. Pakan alami memiliki peran yang belum dapat digantikan oleh pakan buatan seperti memiliki kandungan enzim yang dapat membantu proses pencernaan makanan. Maka dari itu pembudidaya harus bisa melakukan budidaya pakan dengancara pengkulturan pakan alami. Salah satu pakan alami yang bisa dimanfaatkan dalam usaha budidaya ikan adalah pakan alami Spirulina sp.

Spirulina sp. merupakan salah satu pakan alami jenis fitoplankton yang tumbuh pada perairan.Fitoplankton ini memiliki ciriciri berwarna hijau kebiruan berbentuk spiral yang menyerupai benang yang memiliki peranan yang sangat penting di dalam suatu perairan juga merupakan salah satu parameter tingkat kesuburan perairan (Raymont, 1980 dalam Pratiwi dkk, 2012).

Sebagai parameter tingkat kesuburan perairan, Spirulina sp. mengandung nutrisi yang lengkap kaya protein, karbohidrat, lemak dan asam lemak (linolenic acid dan ylinolenic acid), asam amino esensial (leusin, isoleusin dan valin), dan pigmen (klorofil, fikosianin, dan karotenoid). Selain itu, Spirulina sp. juga mengandung vitamin seperti provitamin A, vitamin B12 serta carotene (Koru, 2012 dalam Saepulloh dkk, 2013). Keunggulan lain dari Spirulina sp. adalah mudah dicerna oleh larva udang dan ikan karena memiliki ukuran yang sangat kecil dan sesuai dengan bukaan mulut larva udang dan ikan. Menurut Anonim (2013), Spirulina sp. memiliki dua macam ukuran yaitu jenis kecil berukuran 1-3 mikron meter dan jenis besar berukuran 3-12 mikron meter. Selain memiliki ukuran yang sangat kecil, Spirulina sp. juga mudah dikultur.

Menurut Amri dkk (2018), budidaya Spirulina sp. mudah dikembangbiakkan dan memerlukan waktu yang relatif singkat dalam pemeliharaannya. Untuk mendapatkan fitoplankton ini secara berkesinambungan perlu dilakukan upaya pengkulturan. Kultur Spirulina sp. tidak cukup hanya mengandalkan lingkungan yang bersifat alami. Spirulina sp. sebagai fitoplankton yang hidup di perairan membutuhkan nutrien dengan jumlah yang cukup dan seimbang untuk mencapai pertumbuhan yang optimal. Salah satu teknik kultur yang digunakan adalah dengan pemupukan. Pemupukan bertujuan untuk memastikan fitoplankton tetap tersedia sebagai bahan pakan alami bagi larva udang dan ikan.

Pemberian beberapa jenis pupuk buatan untuk pertumbuhan dan perkembangbiakan pakan alami Spirulina sp. diduga sangat mendukung kelimpahan Spirulina sp. karena pupuk buatan memiliki unsur hara yang cukup untuk pertumbuhannya. Beberapa jenis pupuk buatan yang diduga dapat dijadikan bahan organik untuk kultur Spirulina sp. yaitu pupuk urea, pupuk NPK dan pupuk TSP. Kandungan unsur hara yang terkandung dalam beberapa pupuk tersebut sangat baik untuk kultur Spirulina sp. karena memiliki kandungan unsur hara makro yang mana unsur hara tersebut sangat dibutuhkan oleh fitoplankton. Menurut Sutejo (1987) dalam Rochmady dkk (2017), kandungan unsur hara atau unsur pembangun seperti unsur $\mathrm{N}$, $\mathrm{P}$, dan $\mathrm{K}$ pada pupuk jenis urea 
serta pupuk NPK memiliki kandungan 60\% (N) karena unsur haranya hanya satu yaitu nitrogen, $60 \%(\mathrm{P})$ dan $60 \%(\mathrm{~K})$ karena unsur haranya lebih dari satu yaitu fosfor dan kalium. Sedangkan Pupuk TSP (Triple Super Fosfat) kaya akan kandungan fosfat sekitar 46 - 48\% (Syamdidi dan Amini 2005). Salah satu cara agar Spirulina sp. tumbuh dengan baik yaitu dengan cara menggabungkan ke-3 pupuk tersebut. Oleh karena itu, perlu dilakukan penelitian dengan judul Analisis Pertumbuhan Spirulina sp. dengan Kombinasi Pupuk Berbeda. Adapun tujuan dari penelitian ini adalah untuk mengetahui pengaruh pemberian kombinasi pupuk (urea, NPK dan TSP) dengan dosis berbeda terhadap pertumbuhan Spirulina sp.

\section{METODE PENELITIAN}

Penelitian ini telah dilaksanakan selama 9 hari yaitu pada bulan Oktober 2019 yang bertempat di Instalasi Pribadi Jl. Sultan Salahudin Gg. Manggis Perumahan Geraha Cendana Blok J no 4, Sekarbela, Kota Mataram.

Adapun alat yang digunakan dalam kegiatan penelitian ini adalah sebagai berikut: Saringan, Refraktometer, Termometer, $\mathrm{pH}$ meter, DO meter, Lampu, Tissue, Gelas ukur, Spuit/Suntikan, Mikroskop, Toples , Aerator, Panci, Galon, Kamera, Kompor, Ember, Alat tulis, Sedgewich rafter, Selang aerasi, Batu aerasi, dan Botol sampel.

Adapun bahan yang digunakan dalam kegiatan penelitian ini adalah sebagai berikut: Bibit Spirulina sp., Pupuk urea, Pupuk NPK, Pupuk TSP, Air laut, Air tawar dan Deterjen.

\section{Prosedur Penelitian}

\section{Persiapan Alat dan Bahan}

Wadah yang digunakan dalam penelitian ini berupa toples plastik dengan volume 5 liter sebanyak 12 buah, selang aerasi sebanyak 12 buah dengan panjangmasing masing 1 meter, batu aerasi sebanyak 12 buah, spuit, gelas ukur, dan botol sampel. Sebelum digunakan wadah dan alat yang digunakan dalam penelitian ini harus disterilkan terlebih dahulu dengan cara dicuci dengan menggunakan deterjen dan dibilas hingga bersih dengan air tawar lalu dijemur sampai kering dibawah sinar matahari agar organisme yang menempel terdapat dalam wadah dapat disterilkan. Wadah toples disimpan sesuai dengan denah yang telah dibuat dan dilakukan pemasangan selang dan batu aerasi pada setiap wadah pemeliharaan.

\section{Persiapan Media Air}

Media air dalam penelitian ini diperoleh dari air yang tersedia sekitar pantai Tanjung Bias, Senggigi, Lombok Barat.Air laut terlebih dahulu disaring menggunakan kapas saring, selanjutnya dimasak sampai menidih $\left(\mathrm{suhu} \pm 100^{\circ} \mathrm{C}\right)$ dan setelah itu didinginkan kemudian diukur salinitas awalnya.Salinitas awal yang diperoleh yaitu 30 ppt kemudian ditambah air tawar agar salinitas menjadi 30 ppt. Adapun rumus untuk menghitung salinitas air laut sebagai berikut:

$\mathrm{S}=\frac{\mathrm{S} 1 . \mathrm{V} 1+\mathrm{S} 2 . \mathrm{V} 2}{\mathrm{~V} 1+\mathrm{V} 2}$

Keterangan:

$$
\begin{aligned}
\mathrm{S} & =\text { Salinitas yang diinginkan } \\
\mathrm{S} 1 & =\text { Salinitas air yang akan } \\
\mathrm{S} 2 & \text { diencerkan } \\
\mathrm{V} 1 & =\text { Salinitas air pengencer } \\
\mathrm{V} 2 & =\text { Volume air yang akan } \\
& \text { diencerkan } \\
& =\text { Volume air pengencer }
\end{aligned}
$$

\section{Persiapan Pupuk}

Pupuk (urea, NPK dan TSP) diperoleh dari jasa penyedia pupuk yang telah banyak ditemukan di pasaran.Pupuk (urea, NPK dan TSP) yang dijual di pasar masih dalam 
keadaan kering dan berbentuk butiran kecil sehingga perlu dilakukan penggilingan hingga menjadi bubuk kemudian diayak untuk mendapat partikel partikel yang lebih halus tujuannya agar pupuk mudah larut ketika diencerkan. Selanjutnya pupuk ditimbang sesuai dosis pada masing masing perlakuan. Adapun rumus perhitungan pupuk sebagai berikut:

$\mathrm{N} 1=\mathrm{V} 1 \mathrm{X}$ N1/V2

Keterangan:

V1 = Volume pupuk yang digunakan

V2 = Volume air dalam wadah

$\mathrm{N} 1=$ Berat pupuk

$\mathrm{N} 2=$ Berat pupuk yang dibutuhkan

\section{Persiapan Bibit Spirulina sp.}

Bibit yang digunakan dalam penelitian ini didapat dari online sebanyak $250 \mathrm{ml}$ yang terlebih dahulu dikultur dalam5 liter air untuk memperbanyak stok. Bibit Spirulina sp. ini sebelumnya dihitung terlebih dahulu kepadatanya untuk mengetahui kepadatan yang kita inginkan. Kepadatan bibit pada awal penebaran diatur pada tingkat kepadatan populasi sebesar $10 \mathrm{ind} / 2000 \mathrm{ml}$ pada setiap toples yang bervolume 2 liter. Perhitungan jumlah inokulasi (kultur) menggunakan rumus Edhy dan Kurniawan (2003) dalam Yusanti, dkk (2017) sebagai berikut:

$\mathrm{V} 1=\mathrm{N} 2 \mathrm{X} \mathrm{V} 2 / \mathrm{N} 1$

$$
\begin{array}{rlrr}
\text { V1 } & =\text { Volume Spirulina yang } \\
\text { V2 dibutuhkan } & & \\
\text { N1 } & =\text { Volume air } & & \\
\text { N2 } & =\text { Kepadatan stok } & \text { Spirulina } \\
& \text { (ind/ml) } & & \\
& =\text { Kepadatan Spirulina } & \text { yang } \\
& \text { diinginkan (ind/ml) } &
\end{array}
$$

Penelitian ini menggunakan metode eksperimental dengan rancangan percobaan menggunakan Percobaan Rancangan Acak Lengkap, terdiri dari empat perlakuan dan tiga ulangan. Masing-masing perlakuan yaitu:

Perlakuan A: (0 g/l Urea; 0 g/l NPK; 0g/l TSP) (kontrol)

Perlakuan B: (0,2 g/1 Urea; 0, 01 g/l NPK; $0,004 \mathrm{~g} / 1 \mathrm{TSP})$

Perlakuan C: (0,3 g/1 Urea; 0,02 g/1 NPK; $0,006 \mathrm{~g} / 1 \mathrm{TSP})$

Perlakuan D: (0,4 g/1 Urea; 0,04 g/1 NPK; $0,008 \mathrm{~g} / 1 \mathrm{TSP})$

Dosis diatas penulis mengambil acuan dari penelitian yang dilakukan oleh Alimuddin, dkk (2015) yaitu dengan dosis terbaik 0,3 g/l Urea; 0,02 g/1 NPK; 0,006 g/1 TSPdan kontrol.

Pengamatan yang dilakukan meliputi kepadatan Spirulina sp. laju pertumbuhan harian dan parameter kualitas air.

\section{Kepadatan Spirulina sp.}

Perhitungan kepadatan Spirulina sp. dilakukan setiap harisampai selesai untuk mendapatkan data kepadatan puncak, harian dengan menggunakan sedgewich rafter yang terlebih dahulu dibersihkan dan dikeringkan menggunakan kertas tissu kemudian diteteskan sampel dengan menggunakan suntikan pada wadah yang bervolume $1 \mathrm{ml}$ hingga penuh, lalu tutup dengan cover glass, jangan sampai menimbulkan gelembung udara, selanjutnya sedgwich rafter diamati dibawah mikroskop dengan perbesaran 4 kali.

Menurut Amri dkk (2018), rumus untuk menghitung kepadatan harian Spirulina sp. adalah:

$\mathrm{d}=\mathrm{N} \times 1000 / \mathrm{A}$

Keterangan:

$\mathrm{d}=$ Jumlah kelimpahan fitoplankton

$\mathrm{N}=$ Jumlah fitoplankton yang di amati

A = Jumlah kotak sampel yang di amati

\section{Laju Pertumbuhan Harian Spirulina sp.}

Pertumbuhan adalah perubahan ukuran baik panjang, berat atau volume dalam jangka waktu tertentu. Pertumbuhan ini 
secara fisik diekspresikan dengan adanya perubahan jumlah atau ukuran sel penyusun jaringan tubuh pada periode waktu tertentu. Pertumbuhan Spirulina sp. dapat dilihat dengan melakukan perhitungan laju pertumbuhannya. Perhitungan laju pertumbuhan Spirulina sp. pada saat melakukan kultur harus dilakukan secara kontinue, untuk pakan alami yang mempunyai siklus reproduksi yang singkat hanya dalam hitungan hari maka pemantauan laju pertumbuhan harus dilakukan setiap hari (Anonim, 2013).

Perhitungan laju pertumbuhan Spirulina sp. dilakukan dengan menggunakan alat bantu yaitu Haemocytometer. Menurut Jia (2015) dalam Diansyah dkk (2018), rumus pengukuran laju pertumbuhan harian Spirulina sp. adalah sebagai berikut.

$\mathrm{g}=(\mathrm{In} \mathrm{Nt}-$ In N0)/t

Dimana:

$\mathrm{g}=$ Laju pertumbuhan harian

$\mathrm{Nt} \quad$ (sel/ml/hari)

N0 = Kepadatan sel akhir (ind $/ \mathrm{ml})$

$\mathrm{t}=$ Kepadatan sel awal (ind $/ \mathrm{ml})$

$=$ Selang waktu dari N0 ke Nt (hari)

\section{Parameter Kualitas Air}

Pengambilan data kualitas air merupakan data pendukung yang meliputi suhu, derajat keasaman $(\mathrm{pH})$, salinitas dan oksigen terlarut (DO).Pengambilan data dilakukan setiap hari selama masa penelitian.

\section{HASIL}

Dari hasil pengamatan yang telah dilakukan, diperoleh data mengenai Kepadatan Spirulina sp, Puncak Populasi, Laju Pertumbuhan Harian Spirulina sp, dan Kualitas Air.

\section{Kepadatan Spirulina sp.}

Berdasarkan hasil pengamatan selama penelitian yang dilakukan selama 9 hari proses kultur menunjukan bahwa pemberian kombinasi pupuk (urea, NPK dan TSP) dengan dosis yang berbeda, didapatkan rata rata kepadatan Spirulina sp. seperti dibawah ini. Data pertumbuhan Spirulina sp. dapat dilihat pada Tabel 4.

Tabel 4: Data Rata Rata Kepadatan Spirulina sp. (ind $/ \mathrm{ml}$ )

Waktu Perlakuan

Pengamata

\begin{tabular}{ccccc}
$\mathrm{n}$ & & & & \\
\hline Hari ke & $\mathrm{A}$ & $\mathrm{B}$ & $\mathrm{C}$ & $\mathrm{D}$ \\
\hline 0 & 28 & 28 & 28 & 28 \\
1 & 89 & 91 & 93 & 96 \\
2 & 127 & 129 & 131 & 143 \\
3 & 225 & 273 & 285 & 301 \\
4 & 324 & 356 & 374 & 418 \\
5 & 397 & 438 & 473 & 519 \\
6 & 451 & 527 & 581 & 652 \\
7 & 505 & 623 & 682 & 831 \\
8 & 412 & 535 & 527 & 649 \\
9 & 291 & 320 & 336 & 411 \\
Jumlah & 2.82 & 3.292 & 3.482 & 4.02 \\
Rata rata & 1 & 365,8 & 386,9 & 0 \\
& 313, & & & 446 \\
& 5 & & & 7 \\
\hline
\end{tabular}

Selanjutnya pada gambar memperlihatkan pertumbuhan Spirulina sp. dengan rata rata pertumbuhan yang berbeda untuk setiap perlakuan. 


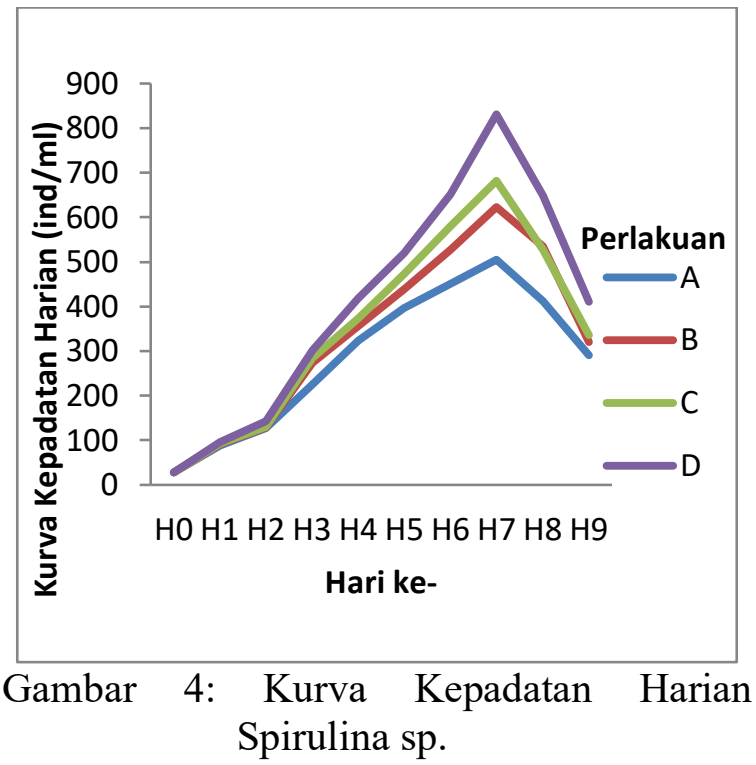

\section{Puncak populasi Spirulina sp.}

Berdasarkan hasil pengamatan selama penelitian kepadatan Spirulina sp. menunjukan bahwa pemberian kombinasi pupuk (urea, NPK dan TSP) dengan dosis yang berbeda menghasilkan kepadatan puncak tertinggi yaitu pada hari ketujuh penelitian, hal ini disebabkan unsur hara yang terdapat pada pupuk (urea, NPK dan TSP) tersebut sudah mulai habis karena telah dimanfaatkan oleh Spirulina sp. untuk proses pertumbuhan. Data puncak populasi Spirulina sp. dapat dilihat pada Tabel 5.

Tabel 5: Data Puncak Populasi Spirulina sp. (ind $/ \mathrm{ml}$ )

\begin{tabular}{cccccc}
$\begin{array}{c}\text { Perlakua } \\
\mathrm{n}\end{array}$ & \multicolumn{2}{c}{ Ulangan } & $\begin{array}{c}\text { Jumla } \\
\mathrm{h}\end{array}$ & $\begin{array}{c}\text { Rat } \\
\mathrm{a} \\
\text { rata }\end{array}$ \\
\cline { 2 - 4 } & 1 & 2 & 3 & & \\
\hline P1 & 52 & 49 & 49 & 1.515 & $505^{\mathrm{a}}$ \\
P2 & 3 & 9 & 3 & 1.869 & 623 \\
P3 & 61 & 62 & 62 & 2.046 & $\mathrm{~b}$ \\
P4 & 6 & 9 & 4 & 2.493 & $682^{\mathrm{c}}$ \\
& 67 & 69 & 67 & & 831 \\
& 9 & 2 & 5 & & $\mathrm{~d}$ \\
& 86 & 84 & 78 & & \\
& 3 & 1 & 9 & & \\
\hline
\end{tabular}

Berdasarkan uji statistik diperoleh hasil bahwa perlakuan menggunakan kombinasi pupuk (Urea, NPK dan TSP) dengan dosis berbedamemberikan pengaruh nyata (signifikan) terhadap nilai puncak populasi. Hasil tersebut dilanjutkan dengan uji Tukey untuk mengetahui perbedaan pada setiap perlakuan. Grafik puncak populasi dapat dilihat pada Gambar 5.

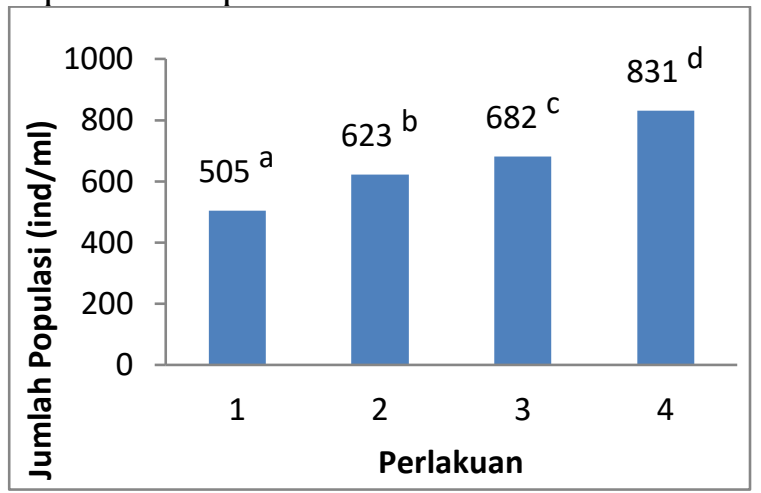

Gambar 5: Grafik Puncak Populasi Spirulina sp.

\section{Laju Pertumbuhan Harian Spirulina sp.}

Laju pertumbuhan harian merupakan parameter yang menggambarkan kecepatan pertumbuhan sel Spirulina sp. persatuan waktu laju pertumbuhan harian dihitung sampai pada saat tercapai kepadatan maksimal.Pengaruh pemberian kombinasi pupuk (Urea, NPK dan TSP) dengan dosis yang berbeda terhadap laju pertumbuhan harian Spirulina sp. disajikan pada Tabel 6.

Tabel 6: Data Laju Pertumbuhan Harian Spirulina sp. (ind/ml/hari)

\begin{tabular}{cc}
\hline Perlakuan & $\begin{array}{c}\text { Laju pertumbuhan } \\
\text { harian } \\
\text { (ind/m1/hari) }\end{array}$ \\
\hline P1 & $0.413^{\mathrm{a}}$ \\
P2 & $0.443^{\mathrm{b}}$ \\
P3 & $0.456^{\mathrm{c}}$ \\
P4 & $0.484^{\mathrm{d}}$ \\
\hline
\end{tabular}


Berdasarkan uji statistik menunjukan kombinasi pupuk urea, pupuk NPK dan pupuk TSP dengan dosis yang berbeda memberikan pengaruh nyata (signifikan) terhadap Laju Pertumbuhan Harian Spirulina sp. Hasil tersebut dilanjutkan dengan uji Tukey untuk mengetahui perbedaan pada setiap perlakuan. Grafik laju pertumbuhan harian Spirulina sp. dapat dilihat pada Gambar 6.

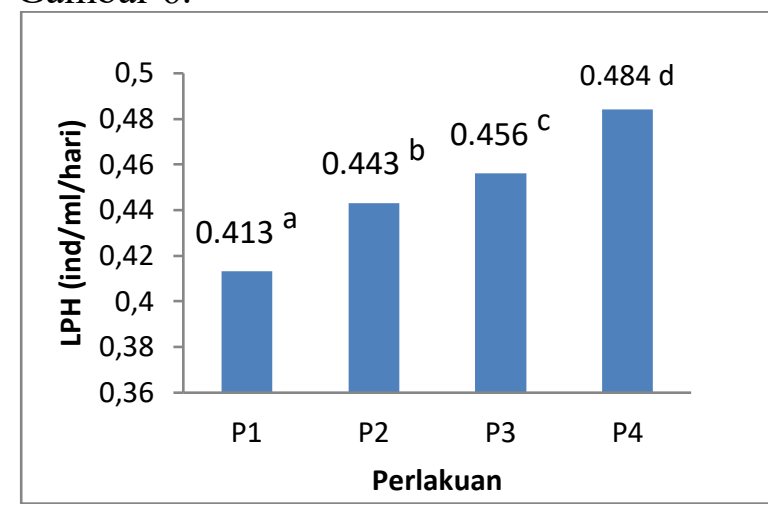

Gambar 6: Grafik Laju Pertumbuhan Harian Spirulina sp.

\section{Parameter Kualitas Air}

Hasil pengukuran kualitas air pada media kulturSpirulina sp. Selama penelitian yaitu dapat dilihat pada Tabel 7.

Tabel 7: Data Pengukuran Kualitas Air

\begin{tabular}{|c|c|c|}
\hline $\begin{array}{l}\text { Kualita } \\
\text { s Air }\end{array}$ & $\begin{array}{l}\text { Kisaran } \\
\text { Hasil } \\
\text { Penguku } \\
\text { ran }\end{array}$ & Kisaran Optimal \\
\hline Suhu & $26-31$ & $\begin{array}{l}25-33^{\circ} \mathrm{C} \\
\text { (Wulandari,2011) }\end{array}$ \\
\hline $\mathrm{pH}$ & $7-7,5$ & $\begin{array}{l}\text { 7-11 (Ciferri, } 1983 \\
\text { dalam Amri, 2018) }\end{array}$ \\
\hline $\begin{array}{l}\text { Salinita } \\
\quad \mathrm{S}\end{array}$ & $30-30$ & $\begin{array}{l}15-30 \text { ppt (Erlina, } \\
2005)\end{array}$ \\
\hline Do & $6-6,3$ & $\begin{array}{l}3,0-5,0 \text { ppm } \\
\text { produktif dan } 7 \text { ppm } \\
\text { produktifnya } \\
\text { (Fox, 1983 } \\
\text { Amri, 2018) }\end{array}$ \\
\hline
\end{tabular}

\section{PEMBAHASAN}

\section{Kepadatan Spirulina sp.}

Pertumbuhan Spirulina sp. terjadi dalam 4 fase yaitu fase lag (fase adaptasi), fase Eksponensial (fase logaritmik), fase stasioner (fase pertumbuhan dan kematian) dan fase deklinasi (fase penurunan laju pertumbuhan dan kematian). Siklus pertumbuhan Spirulina sp. terjadi selama 9 hari dari fase lag sampai fase kematian.

Fase lag pada setiap perlakuan terjadi pada hari pertama. Fase lag terjadi selama 1 hari setelah penambahan inokulan kedalam media penelitian. Fase lag atau fase adaptasi merupakan fase ketika kepadatan sel tidak mengalami perubahan, tetapi ukuran sel pada fase tersebut meningkat. Hal ini menunjukan bahwa Spirulina sp. yang dikultur pada media pupuk mampu beradaptasi dengan baik dan mampu memanfaatkan nutrien yang terkandung dalam pupuk untuk membelah diri dengan cepat (Yusanti, 2017).

Fase eksponensial merupakan fase pertumbuhan yang terjadi peningkatan jumlah sel secara cepat. Diawali dengan terjadinya pembelahan sel dengan laju pertumbuhan yang terjadi terus menerus, fase eksponesial ditandai dengan naiknya laju pertumbuhan sehingga kepadatan populasi Spirulina sp. meningkat. Fase eksponensial terjadi pada hari ke-2 sampai dengan pada hari ke-7 jumlah Spirulina sp. mengalami kenaikan. Hal ini disebabkan karena media tempat pertumbuhan Spirulina sp. kaya akan nutrien yang sangat diperlukan untuk pertumbuhan (Hariyati, 2008).

Pada hari ke-7 sampai dengan hari ke8 merupakan fase Stasioner, dimana laju pertumbuhan Spirulina sp. sudah mulai menurun. Pada fase ini kelimpahan Spirulina sp. mencapai puncak populasi. Hal ini disebabkan karena jumlah nutrien dalam media sudah semakin berkurang, tetapi walaupun demikian sel sel Spirulina sp. 
masih dapat membelah tetapi jumlah tidak sebanyak pada fase eksponensial (Hariyati, 2008).

Fase kematian pada kultur Spirulina sp yaitu terjadi pada hari ke-9, dimana Fase kematian merupakan fase ketika terjadi penurunan jumlah atau kepadatan mikroalga. Menurunnya kepadatan sel Spirulina sp. disebabkan karena padatnya sel Spirulina sp. yang menyebabkan persaingan untuk memanfaatkan nutrien sehingga berkurangnya kandungan nutrien yang terkandung didalam media kultur. Hal ini sesuai dengan pernyataan Hariyati (2008), penurunan pertumbuhan dapat disebabkan oleh (1) Berkurangnya nutrien dalam media, (2) Berkurangnya intensitas cahaya karena penaungan sendiri, (3) kompetisi yang semakin besar dalam mendapatkan nutrien, ruang hidup dan cahaya.

Berdasarkan kurva kepadatan Spirulina sp. yang dikultur selama 9 hari dengan berbagai perlakuan kombinasi pupuk (urea, NPK, TSP) menunjukan bahwa kepadatan puncak pada perlakuan A, B, C dan $\mathrm{D}$ terjadi pada hari ke-7. Hal ini disebabkan karena media tempat pertumbuhan Spirulina sp. kaya akan kandungan nutrien yang sangat diperlukan untuk pertumbuhannya (Hariyati, 2008).

Kepadatan puncak tertinggi terdapat pada perlakuan $\mathrm{D}$, hal ini disebabkan karena kombinasi pupuk (urea, NPK dan TSP) dengan dosis sebanyak $(0,4 \mathrm{~g} / 1$ Urea; 0,04 $\mathrm{g} / 1 \mathrm{NPK} ; 0,008 \mathrm{~g} / 1 \mathrm{TSP})$ yang diberikan pada media kultur sesuai untuk kebutuhan hidup Spirulina sp. Hal ini sangat berbeda dengan perlakuan $\mathrm{B}$ dan $\mathrm{C}$ dengan kombinasi pupuk (urea, NPK dan TSP) sebanyak (0,2 g/1 Urea; 0, 01g/1 NPK; 0,004 g/1 TSP) dan (0,3 g/1 Urea; 0,02 g/1 NPK; 0,006 g/1 TSP), dimana kepadatan Spirulina sp yang dihasilkan tidak terlalu tinggi. Hal ini diduga karena dosis pupuk yang diberikan belum sesuai dan belum tepat. Sedangkan pada perlakuan A (kontrol) tanpa penambahan pupuk didalam media kultur menunjukkan pertumbuhan yang paling rendah di sebabkan karena pada perlakuan A (tanpa pupuk) tidak diberi kombinasi pupuk (urea, NPK dan TSP) sebagai unsur hara tambahan. Hal ini akan menyebabkan pertumbuhan tidak optimal, karena tidak ada unsur hara tambahan sehingga pertumbuhannya mengalami kematian yang lebih cepat.

\section{Puncak Populasi Spirulina sp.}

Puncak populasi terhadap kepadatan sel Spirulina sp. berdasarkan uji Tukey menunjukkan bahwa P1 berbeda nyata terhadap perlakuan P2, perlakuan P2 berbeda nyata terhadap perlakuan P3, Perlakuan P3 berbeda nyata terhadap perlakuan P4 sedangkan P4 berbeda sangat nyata terhadap perlakuan P1. Hal tersebut dapat di buktikan dari perbedaan kepadatan sel Spirulina sp. yang dihasilkan pada setiap perlakuan dengan dosis pupuk yang berbeda.

Puncak Spirulina sp. dihitung dengan melihat kenaikan jumlah ind/ml tertinggi pada saat penelitian. Berdasarkan grafik puncak populasi terhadap kepadatan sel Spirulina sp. menunjukan bahwa pada perlakuan P1 sebanyak $505 \mathrm{ind} / \mathrm{ml}$, perlakuan P2 sebanyak $623 \mathrm{ind} / \mathrm{ml}$, perlakuan P3 sebanyak $682 \mathrm{ind} / \mathrm{ml}$ dan perlakuan P4 sebanyak $831 \mathrm{ind} / \mathrm{ml}$. Dari masing masing perlakuan dapat dilihat bahwa puncak populasi terbaik pada perlakuan P4 kemudian di ikuti oleh P3, P2 dan P1.

Perlakuan P1 ( tanpa pupuk) menunjukan kepadatan sel terendah, hal ini disebabkan karena pada perlakuan P1 tidak diberi kombinasi pupuk (urea, NPK dan TSP) sebagai unsur hara tambahan sedangkan pada Perlakuan P4 (0,4 g/1 urea; 0,04 g/l NPK; 0,008 g/l TSP) dengan dosis pupuk tertinggi menunjukan kepadatan sel tertinggi. Hal ini diduga karena perlakuan P4 kombinasi dosis pupuk atau kebutuhan nutrien yang diberikan sudah terpenuhi 
secara seimbang. Cahyaningsih (2016) dalam Amri (2018), menyatakan bahwa hasil dari puncak populasi merupakan karena adanya pengaruh nutrien yang terkandung didalam media kombinasi pupuk (urea, NPK, TSP) yang meliputi unsur hara makro dan mikro yang memenuhi kebutuhan nutrien Spirulina sp.

\section{Laju Pertumbuhan Harian Spirulina sp.}

Laju pertumbuhan harian sel Spirulina sp. berdasarkan uji Tukey menunjukan bahwa P1 berbeda nyata terhadap perlakuan P2, perlakuan P2 berbeda nyata terhadap perlakuan P3, Perlakuan P3 berbeda nyata terhadap perlakuan P4 sedangkan P4 berbeda sangat nyata terhadap perlakuan P1. Hal tersebut dapat di buktikan dari perbedaan laju pertumbuhan harian Spirulina sp. yang dihasilkan pada setiap perlakuan dengan dosis pupuk yang berbeda.

Berdasarkan grafik laju pertumbuhan harian Spirulina sp. pada setiap perlakuan P1, P2, P3 dan P4 yaitu pada perlakuan P1 sebanyak $0.413 \mathrm{ind} / \mathrm{ml} /$ hari, Perlakuan P2 sebanyak $0.443 \mathrm{ind} / \mathrm{ml} /$ hari, Perlakuan P3 sebanyak 0.456 ind $/ \mathrm{ml} /$ hari dan $\mathrm{P} 4$ sebanyak $484 \mathrm{ind} / \mathrm{ml} /$ hari. Dari masing masing perlakuan dapat dilihat bahwa nilai laju pertumbuhan terbaik pada perlakuan P4 kemudian disusul oleh P3, P2 dan P1. Perlakuan P1 menunjukan pertumbuhan terendah (tanpa pupuk) tidak ada pemberian unsur hara.

Perbedaan laju pertumbuhan harian pada setiap perlakuan tersebut disebabkan oleh kemampuan sel dalam menyerap unsur hara yang terdapat dalam media kultur. Selain itu, perbedaan laju pertumbuhan harian juga di pengaruhi oleh faktor nutrisi yang terkandung pada media kultur. Djariah (1995) dalam Yusanti (2017), yang menyatakan bahwa media pupuk berpengaruh pada laju pertumbuhan karena laju pertumbuhan fotosintesis mikroalga di pengaruhi oleh faktor nutrisi yang terdapat pada media kultur.

\section{Kualitas Air}

Pertumbuhan Spirulina sp. selain dipengaruhi oleh kandungan nutrisi pada pupuk juga dipengaruhi oleh faktor lingkugan atau kualitas air yaitu kondisi fisika dan kimia dari medianya. Kondisi fisika meliputi suhu, intensitas cahaya dan aerasi. Sementara kondisi kimia meliputi $\mathrm{pH}$, salinitas dan oksigen terlarut.

Suhu selama penelitian mencapai kisaran 26 hingga $31^{\circ} \mathrm{C}$. Pada kisaran tersebut organisme dapat tumbuh dengan baik. Hal ini sesuai dengan pendapat Wulandari (2011), yang mengatakan bahwa suhu merupakan faktor yang menentukan pertumbuhan mikroalga. Spirulina sp. termasuk kedalam mikroalga mezofilik yang dapat tumbuh pada temperatur $20-40^{\circ} \mathrm{C}$ dengan suhu optimum pertumbuhanya 25 $33^{\circ} \mathrm{C}$. Apabila suhu kurang dari $25^{\circ} \mathrm{C}$ pertumbuhan Spirulina sp. akan terganggu.

Nilai $\mathrm{pH}$ pada penelitian mencapai kisaran antara 7 hingga 7,5. Nilai tersebut baik untuk pertumbuhan Spirulina sp., hal ini sesuai dengan pendapat Ciferri (1983) dalam Amri (2018), menyatakan bahwa $\mathrm{pH}$ yang baik untuk pertumbuhan Spirulina sp berkisar antara 7-11.

Salinitas hasil pengamatan selama penelitian berkisar antara 30 ppt. Kisaran salinitas tersebut baik untuk pertumbuhan Spirulina sp. hal ini sesuai dengan pendapat Erlina dkk (2005), yang mengatakan bahwa Salinitas berpengaruh terhadap organisme air dalam mempertahankan tekanan osmotik dengan lingkunganya, Spirulina sp. bersifat euryhaline dengan kisaran salinitas antara 15-30 ppt. Selain itu, Spirulina sp. dapat tumbuh juga dalam media air bersalinitas tinggi. Hal ini sesuai dengan pendapat Isnansetyo dan Kurniastuti (1995) dalam Diansyah (2018), beberapa mikroalga laut 
tumbuh dengan optimal pada kisaran salinitas 35 ppt.

Hasil pengukuran DO selama penelitian berkisar anatra 6 ppm hingga 6,3 ppm. Nilai oksigen terlarut yang diperoleh termasuk sesuai untuk pertumbuhan Spirulina sp. Menurut Fox (1983) dalam Amri (2018), yang mengatakan bahwa oksigen (O2) terlarut 3.0-5.0 ppm kurang produktif dan diatas $7 \mathrm{ppm}$ sangat tinggi produktifitasnya. Nilai kualitas air pada penelitian ini masih dikatakan cocok dan baik untuk kebutuhan hidup Spirulina sp.

\section{KESIMPULAN}

Berdasarkan hasil penelitian dapat disimpulkan bahwa:

1. Kombinasi pupuk urea, pupuk NPK dan pupuk TSP pada kultur Spirulina sp. berpengaruh nyata terhadap kepadatan, puncak populasi dan laju pertumbuhan harian Spirulina sp. dengan dosis terbaik terdapat pada perlakuan D dengan perbandingan pupuk urea, pupuk NPK dan pupuk TSP sebesar(0,4 g/1 Urea; 0,04 g/l NPK; 0,008 g/1 TSP).

2. Kondisi kualitas air pada penelitian masih berada pada kisaran optimal sehingga dapat disimpulkan masih layak dan sesuai kebutuhan hidup Spirulina sp.

\section{DAFTAR PUSTAKA}

Anonim. 2013. Produksi Pakan Alami. Paket Keahlian Budidaya Rumput Laut. Buku Teks Bahan Ajar Siswa, Hal 1278.

Amri, M.C., Mulyani, dan Eva, A. 2018. Pengaruh Pemberian Pupuk Kascing (bekas cacing) yang Di Fermentasi dengan Dosis yang Berbeda Dalam Kultur Spirulinasp. Acta Aquatic: Aquatic Sciences Journal, 5(1), 30-35.

Alimuddin, A.H., Rahmi, P., dan Nelly, W. 2015. Uji Fotostabilitas TiO2-Klorofil Dari Mikroalga (Chlorella sp.).JKK,4(2), 76-80.
Christiani, Widyastuti, E., dan Putri, F.D.M. 2014. Hubungan Perbaningan Total Nitrogen dan Total Fosfor dengan Kelimpahan Chrysophyta Di Perairan Waduk Panglima Besar Soedirman, Banjar Negara. Jurnal. Fakultas Biologi, Universitas Jendral Soedirman, Jalan dr. Suparno 63 Purwokerto.

Ciferri, O. 1983. Spiruli..., The Edible Microorganism. Microbiological Reviews. American Society for Microbiology, 47(4),551-578.

Diansyah, G., Iklima, D., dan Isnaini. 2018. Kultivasi Mikroalga Chaetoceros sp. dan Spirulina sp. Untuk Potensi Biodiesel. Jurnal. Program Studi Ilmu Kelautan, FMIPA, Universitas Sriwijaya, Indralata, Indonesia.

Effendi, H. 2003. Telaah Kualitas Air Bagi Pengelolaan Sumber Daya dan Lingkungan Perairan. Yogyakarta.

Erlina, A., Utomo, N.B.P., dan Winarti. 2005. Pertumbuhan Spirulina platensis yang Dikultur dengan Pupuk Inorganik (urea, TSP dan ZA) dan Kotoran Ayam. $N$ rari Journal, 10(2), 123-130.

Fauzan, A., dan Firdaus, M. 2015.Produksi dan Kandungan Nutrisi Spirulina fusiformis yang Di Kultur dengan Pencahayaan Monokromatis Light Emitting Diodes (LEDs). Jurnal Riset Akuakultur, 10(2), 211-219.

Hadiyanto, M., Christawardana, M.M.A., dan Nur. 2013. Spirulina platensis, Fotensinya sebagai Bahan Pangan Fungsional. Jurnal Aplikasi Teknologi Pangan, 2(1), 1-4.

Hariyati, R. 2008. Pertumbuhan dan Biomasa Spirulina sp. dalam Skala Laboratoris. Laboratorium Ekologi dan Biosistematik. Jurusan Biologi. FMIPA. Semarang Universitas Diponegoro, 10(1), 19-22. 
Limantara, L., dan Prasetyandaru, P. 2008. Pigmen Spirulina sebagai Senyawa Antikanker. Indonesia Journal Of Cancer 4, 155-163.

Nurhasanah, R.Q., dan Buwono, N.R. 2018. Studi Pertumbuhan Populasi Spirulina sp. pada Skala Kultur yang Berbeda.Jurnal Ilmiah Perikanan dan Kelautan, 10(1), 35-46.

Prasetyo, B., dan Elizabeth, N.K. 2010. Penentuan Jenis Spirulina sp. Di Situ Babakan, Jagakarsa, Jakarta Selatan. Laporan Penelitian.

Pratiwi, N.T.M., Yuliana, Enan, M., Adiwilaga, dan Enang.2012. Hubungan Antara Kelimpahan Fhytoplankton dengan Parameter Fisika Kimiawi Perairan Di Teluk Jakarta. Jurnal Akuatika, 3(2), 169179.

Purwiyanto, A.I.S., Zafira, A., dan Gusti, D. 2014. Pengaruh Pemberian Pupuk Urea (CH4N2O) dengan Dosis Berbeda terhadap Kepadatan Sel dan Laju Pertumbuhan Porphydium sp. pada Kultur Fhytoplankton Skala Laboratorium. Maspari Jurnal, 7(2), 33-40.

Risamasu, F.J.L., dan Prayitno, H.B. 2011. Kajian zat hara fosfat, nitrit, nitrat dan silikat di perairan Matasisi, Kalimantan Selatan. Ilmu Kelautan,16(3), 135-142.

Riyono, S.H. 2007. Beberapa Sifat Umum dari Klorofil Fitoplankton. Jurnal Oseana, xxxii(1), 23-31.

Robi, N.H. 2014. Pemanfaatan Ekstrak Tauge Kacang Hijau (Phaseolus radiates) sebagai Pupuk untuk Meningkatkan Populasi Spirulina sp. Skripsi. Program Studi Budidaya Perairan, Universitas Perikanan dan Kelautan, Universitas Airlangga.

Rochmady, Fitriani, dan Fendi. 2017. Pengaruh Pemberian Pupuk Anorganik (NPK+Silikat) dengan Dosis Bebeda terhadap Kepadatan Skletonema costatum pada Pembenihan Udang Windu. Jurnal Akuakultur, Pesisir dan Pulau Pulau Kecil, 1(1), 11-18.

Saepulloh, Prima, B.A., Yusup, S., dan Aep, S. 2013. Pertumbuhan Mikroalga Spirulina platensis dalam Efluen Industry Kertas. Jurnal Selulosa Tropis, 3(2), 97-102.

Supriyantini, E., Ridlo, A., dan Sedjati, A. 2015. Aktivitas Anti Oksidan Fikosianin Dari Spirulina sp. Menggunakan Metode Transfer Elektron dengan DPPH (1,1-difenil-2pikrilhidrosil). Jurnal Kelautan Tropis, 18(2), 58-63.

Syamdidi, dan Amini, S. 2005. Konsentrasi Unsur Hara pada Media dan Pertumbuhan Chllorela vulgaris dengan Pupuk Anorganik Teknis dan Analis. Jurnal Perikanan, 6(2), 201206.

Wulandari, N.D.A. 2011. Penggunaan Media Alternative pada Produksi Spirulina fosiformis. Skripsi. Departemen Budidaya Perairan, Fakultas Perikanan dan Ilmu Kelautan, Institute Pertanian Bogor.

Yusanti, A.I., Anggra, W.L., dan Dian, M. 2017. Penggunaan Pupuk Organik Cair Hasil Fermentasi dari Azolla finnata terhadap Kepadatan Sel Spirulina sp. Fakultas Prikanan, Universitas PGRI Palembang. Jurnal Ilmu Ilmu Perikanan dan Budidaya Perairan, 12(1), 56-65. 